
w polskich tekstach literackich. Slavia Meridionalis, 21, Article 2428. https://doi.org/10.11649/sm.2428

\author{
Anna Tyrpa \\ Instytut Języka Polskiego \\ Polskiej Akademii Nauk \\ https://orcid.org/0000-0001-5365-5535
}

\title{
Słownictwo z zakresu komunikacji międzyludzkiej w polskich tekstach literackich
}

Jako wstęp do tego artykułu przywołam myśli zawarte w tekście Franciszka Nieckuli (Nieckula, 1993). Pisze on, że alfabet wynaleziono około 3000 lat temu, a druk - około 500 lat temu.

Druk spowodował (od XVI w. masowa książka, od XVIII w. również gazety) rozwój komunikacji ponadplemiennej i ponadnarodowej, komunikacji w obrębie całej wspólnoty językowej oraz towarzyszący postępowi naukowemu i technicznemu wzrost specjalizacji w społecznym podziale pracy [...] (Nieckula, 1993, s. 108)

Dla zrozumienia rangi druku trzeba porównać to, czego dokonała ludzkość w dziedzinie kultury i cywilizacji w ciągu ostatnich 500 lat $\mathrm{z}$ dorobkiem wcześniejszych 2500 lat. (Nieckula, 1993, s. 109)

Upowszechnienie druku spowodowało szybszy przepływ informacji, a to pociągnęło za sobą duże przyśpieszenie rozwoju cywilizacji. Porównując

This work was supported by the Polish Ministry of Education and Science.

Competing interests: no competing interests have been declared.

Publisher: Institute of Slavic Studies, Polish Academy of Sciences.

This is an Open Access article distributed under the terms of the Creative Commons Attribution 3.0 PL License (creativecommons.org/licenses/by/3.0/pl/), which permits redistribution, commercial and non-commercial, provided that the article is properly cited. ๑ The Author(s) 2021. 
znaczenie druku dla postępu techniki ze znaczeniem kolejnych wynalazków w dziedzinie komunikacji międzyludzkiej, zauważamy tę samą prawidłowość. Telegraf, telefon, radio, telewizja i komputer - każde z tych urządzeń ułatwia porozumiewanie się ludzi na odległość, a zatem wspomaga rozwijanie się wielu gałęzi ludzkiej działalności. Wydaje się, że w ostatnich latach tempo tego rozwoju jest zawrotne.

W niniejszym tekście pragnę zająć się dwoma urządzeniami, które wynalezione w latach 40. XX wieku - komputer (STM, 2006, s. 98) i w latach 70. XX wieku - telefon komórkowy (STM, 2006, s. 215), w wieku XXI stanowią nieodłączny element życia społecznego.

$Z$ reguły badacze zajmujący się leksyką związaną z nowymi środkami przekazu skupiają uwagę na materiale zaczerpniętym z Internetu. Rozpatrują nowe gatunki mowy, jak blog (Aleksandruk, 2012; Ginter, 2018; Suska, 2015) i czat (Jędrzejko, 2012; Szymański, 2009, 2011, 2012, 2013). Analizują nowe zapożyczenia angielskie w polszczyźnie internetowej (Niepytalska-Osiecka, 2014). Zainteresowaniem objęte są też antroponimy używane w sieci (Kojder, 2015; Legomska, 2015; Naruszewicz-Duchlińska, 2015).

Również autorzy opracowań skupionych na innym temacie, poświęcają leksyce związanej z komunikacją międzyludzką sporo uwagi. Tak ma się w przypadku pracy zespołowej Języki zachodniosłowiańskie wobec pożyczek angielskich w ostatnim dwudziestoleciu. Gramatyka, leksyka, pragmatyka, uwarunkowania społeczno-kulturowe (Greń i in., 2016). Badania przeprowadzone na bogatym materiale (głównie z prasy) wykazały, że właśnie ta sfera ludzkiej działalności dostarczyła wielkiej liczby nowych zapożyczeń angielskich:

Niewątpliwie rozwój cywilizacyjny związany z upowszechnieniem się internetu oraz rozwojem technologicznym zdecydowanie wpłynął na życie codzienne człowieka. Pojawianie się w powszechnym użyciu nowych produktów, np. sprzętu elektronicznego, komputerowego, telekomunikacyjnego, sportowego, spowodowało konieczność ich nazwania. Dużą rolę w tym procesie odgrywają anglicyzmy. Jest to zrozumiałe, bowiem dominującą rolę w postępie technologicznym na świecie odgrywają Stany Zjednoczone.

Sfery internet, informatyka, komputery to ponad 570 zapożyczeń, technika i technologia oraz telekomunikacja to 850 zapożyczeń, co stanowi ponad $20 \%$ zebranego materiału (Holly \& Żółtak, 2016, s. 208)

Moim zamiarem jest ukazanie, jak leksyka telefoniczna i komputerowa przenika do literatury pięknej. Wiąże się to $\mathrm{z}$ tematyką utworów $\mathrm{z}$ dwóch pierwszych dekad XXI wieku, która nie pomija zagadnień związanych z obec- 
nością nowoczesnych mediów. Przywołam słowa z tego kręgu tematycznego wraz z ilustrującymi je cytatami. Natomiast nie zamierzam prowadzić analizy formalnej zebranych zapożyczeń angielskich ani ich polskich ekwiwalentów i derywatów. Chciałabym jedynie zasygnalizować, że autorzy współczesnych utworów literackich dokumentują fazy przyswajania zapożyczeń angielskich w polszczyźnie potocznej - od cytowania, poprzez dostosowania do pisowni i fleksji polskiej, po wprowadzanie polskich ekwiwalentów i ich derywatów (np. like, lajk, lubię, polubienie; scroll, skrolować, przewijać; sms, esemes, wiadomość). Ten proces przedstawia w swoim opracowaniu Zbigniew Greń:

W interesującym nas [...] zakresie - wprowadzania obcych elementów do systemu leksykalnego - skala możliwości postępowania rozciąga się od braku jakiejkolwiek ingerencji w znaczenie i formę przyjmowaną (jednostki tak przyjmowane funkcjonują w języku przyjmującym na zasadzie cytatu obcojęzycznego) do maksymalnej adaptacji na wszystkich płaszczyznach funkcjonowania jednostek leksykalnych od ortografii przez fonetykę, fleksję, właściwości składniowe i słowotwórcze, po semantykę (Greń, 2015, s. 125).

Teresa Smółkowa zauważa, że „[w]ariantywność ortograficzna pożyczek angielskich jest uderzającą cechą tej grupy wyrazów" (Smółkowa, 2015, s. 232). Objawia się ona nawet podawaniem różnych wariantów ortograficznych niektórych zapożyczeń z języka angielskiego jako wyrazów hasłowych w słownikach. Normalizacja zapisów nie nadąża za tempem pojawiania się nowych obcych leksemów w polszczyźnie. W monografii Języki zachodniosłowiańskie (Greń i in., 2016) opisano procesy adaptacji zapożyczeń angielskich w trzech językach: czeskim, polskim i słowackim.

Zamierzam pokazać, jak słownictwo związane $\mathrm{z}$ dwoma przedmiotami służącymi komunikacji między ludźmi odbija się na kartach współczesnej prozy polskiej. Mój materiał to 11 powieści obyczajowych (Joanny Bator, Kingi Dunin, Katarzyny Michalak, Małgorzaty Musierowicz i Moniki Szwai), 3 powieści kryminalne (Małgorzaty i Michała Kuźmińskich oraz Remigiusza Mroza) i zbiór felietonów Mariusza Szczygła. Są to utwory z lat 1998-2019, czyli z ostatniego dwudziestolecia, w których współczesne sposoby komunikowania się stanowią istotny składnik treści.

Objaśnienia terminów telekomunikacyjnych i informatycznych czerpałam ze Słownika terminologii medialnej (STM, 2006), ale ponieważ ukazał się on w roku 2006, nie wszystkie hasła pojawiające się w później powstałej literaturze pięknej znalazły się w tym kompendium. Tych nowszych szukałam w Wikipedii. 


\section{Telefony}

Wynalazkiem, który znacznie ułatwił komunikowanie się ludzi, był telefon, opatentowany przez A. G. Bella w 1876 roku. Niecałe sto lat później, w roku 1973, uruchomiono pierwszy telefon komórkowy (STM, 2006, ss. 214-215). Telefony komórkowe (osobiste, przenośne, służące do rozmów w każdym miejscu) pojawiły się w Polsce w 1992 roku i z czasem weszły do powszechnego użytku. Zdarzają się jednak osoby, które nie chcą korzystać z tego wynalazku:

(1) Zadzwoniłam do matki, ale nie było jej w domu. Odpowiedział mi mój własny głos, który dawno temu nagrałam. [...] Moja matka nie miała telefonu komórkowego i nie chciała go mieć. Posługiwała się starodawnym stacjonarnym aparatem $\mathrm{z}$ automatyczną sekretarką. Lubiła podnosić słuchawkę, nie wiedząc, kto dzwoni (Bator, 2017, s. 237).

Zauważmy, że słowo aparat, będące tu skrótem wyrażenia aparat telefoniczny, jest opatrzone określeniem stacjonarny. Przymiotnik ten zaczął towarzyszyć rzeczownikowi telefon dopiero po rozpowszechnieniu się telefonów komórkowych, w celu odróżnienia od siebie tych dwóch typów. Urządzenie do nagrywania komunikatów w razie braku bezpośredniego kontaktu nadawcy $\mathrm{z}$ odbiorcą $\mathrm{w}$ telefonach dawnego typu nazywano sekretarka automatyczna (jak w powyższym cytacie), a w komórkowych poczta głosowa.

Niekiedy telefon komórkowy nazywany jest po prostu telefonem:

(2) Grupka nastolatków przy zaparkowanej w rowie hondzie civic nagrywała telefonem odjeżdżające auta (Kuźmińska \& Kuźmiński, 2019, s. 35).

Można łatwo się domyślić, że chodzi o telefon komórkowy, bo trudno sobie wyobrazić telefon $\mathrm{z}$ podłączonym przewodem - $\mathrm{w}$ rowie, a poza tym to telefony komórkowe mają zainstalowane kamery służące do nagrywania filmów. Powyższy fragment świadczy o „zwycięstwie” telefonów komórkowych nad tymi zależnymi od przewodów. Zbędny stał się przymiotnik komórkowy; teraz to jest „normalny, zwykły” telefon.

O wiele częściej wyrażenie telefon komórkowy jest zredukowane do rzeczownika komórka:

(3) - Oboje mamy komórki, nieprawdaż? (Szwaja, 2005, s. 53).

Oprócz filmowania, telefonem komórkowym można robić zdjęcia:

(4) - W wiadomości było zdjęcie... Zdjęcie Ani... [...] - Zdjęcie musiałem skasować, a potem ściągnąć apkę, która zablokowała cały telefon... (Mróz, 2019, s. 329). 
Apka to potoczny odpowiednik słowa aplikacja.

Autorzy współczesnej prozy wymieniają w swoich tekstach poszczególne części i funkcje telefonów komórkowych:

(5) ekran: [...] taka wiadomość, wysłana z nieznanego adresu internetowego, wyświetliła się nocą na ekranie mojej komórki [...] (Bator, 2012, s. 122).

(6) wyświetlacz: [...] usłyszała krótki sygnał w słuchawce i rzuciwszy okiem na wyświetlacz, zobaczyła połączenie oczekujące od Bastiana (Kuźmińska \& Kuźmiński, 2019, s. 95).

(7) karta SIM: - Wszyscy rzucili się do mnie z komórkami [...] ale nie pamiętałam twojego numeru. A nikt nie miał samsunga, żeby zamienić karty SIM [...] (Szwaja, 2005, s. 53).

(8) głośnik: - Daj na głośnik - powiedziała obcesowo Katarzyna, przechyliła się w strone Adeli i bezceremonialnie wcisnęła prztyczek od głośnika w jej aparacie (Szwaja, 2005, s. 292).

(9) zestaw głośnomówiący: - Włącz telewizor, właśnie w radiu mówili, że coś się dzieje w Dąbrowie! - przekrzykiwała silnik przez zestaw głośnomówiący. - Ja już tam pędzę, jestem przy zjeździe w Mościcach, pojadę prosto pod synagogę (Kuźmińska \& Kuźmiński, 2019, s. 93).

(10) alarm: Obudził mnie alarm nastawiony na siódmą (Bator, 2017, s. 87).

Alarm w komórce to odpowiednik dawniejszego zegarka - budzika. Jednym z urządzeń, które można mieć w telefonie komórkowym, jest nawigacja satelitarna, czyli GPS, zapisywany również jako dżipies:

(11) - Wiesz gdzie to jest? - Mam GPS. [...] - Czy pani słyszy samą siebie? - spytał w zadumie. - Dżipiesy, esemesy, abeesy, same skróty. Żeby było szybciej. Wam, młodym, stale gdzieś pociągi odchodzą, wszyscy zabiegani, zaaferowani i na normalność nikt nie ma czasu (Szwaja, 2009, ss. 198-199).

W powyższym cytacie pojawiło się słowo esemesy. Jest to sposób na zapisanie skrótu SMS, za którym kryje się angielskie wyrażenie Short Message Service 'usługa krótkiego przekazu' (STM, 2006, s. 198). Esemesy się pisze:

(12) - Ona jest w ogóle biedna, ta pańska córeczka [...] Mam na myśli mamusię na Kilimandżaro i tatusia na pięknym żaglowcu. A do córeczki piszemy esemesy (Szwaja, 2008, s. 289).

Esemesy się wysyła:

(13) [...] zawołał sekretarkę i wydał jej polecenie. A ona ci wysłała tego esemesa (Szwaja, 2005, s. 293).

Obecnie można generować tekst pisany, mówiąc, lub nagrywać tekst mówiony, który odbiorca następnie odsłuchuje, jednak nie znalazłam poświadczeń tych technik w powieściach. 


\section{Utworzono przysłówek esemesowo:}

(14) [...] w kieszeni Adeli zadzwoniła komórka. Krótko, esemesowo (Szwaja, 2005, s. 292).

\section{Niektórzy autorzy stosują zapis SMS:}

(15) Dźwięk SMS-a wyrwał ją z płytkiego snu (Kuźmińska \& Kuźmiński, 2019, s. 281).

W dwóch powyższych fragmentach $(14,15)$ poświadczono, że w chwili przychodzenia wiadomości na komórkę, rozlega się sygnał powiadamiający o tym właściciela telefonu.

Stosuje się też polski odpowiednik słowa message - wiadomość:

(16) Spróbowałam odpowiedzieć na esemesa, którego przysłał mi kiedyś z zastrzeżonego numeru, ale system poinformował mnie, że wiadomość nie może zostać wysłana (Bator, 2012, s. 348).

Natomiast wyrażenie wiadomość tekstowa odczuwane jest jako zbyt oficjalne:

(17) - Umówiliśmy się, że przedzwoni do mnie co jakiś czas albo wyśle wiadomość tekstową. Gocha uśmiechnęła się i bezradnie pokręciła głową. - Jesteś jedyną osobą na świecie, która odmówiłaby darmowego aperolu ${ }^{1}$. I jedyną, która na esemesa mówi „wiadomość tekstowa”. - Na pewno nie jedyną. - Tak czy inaczej, należysz do wymierającego gatunku (Mróz, 2019, s. 482).

Teksty literackie czasem rejestrują nazwy firm produkujących telefony, a nazwy te zaczynają odnosić się do aparatów, będących dziełem owych firm:

(18) - Och, bo ileż razy mówiłem ci, że trzeba sobie kupić nokię! - Och, wiem, większość białych ludzi ma nokię! I gdybym ja też miała nokię, jak biały człowiek, to by zapobiegło całej tej historii [...] (Szwaja, 2005, ss. 53-54).

Komórki informują o połączeniu różnymi dźwiękami. Czasem w tytule melodii zawarta jest nazwa firmy produkującej telefony:

(19) Siedział w dresie przed telewizorem, w pokoju obok Ewa spała jak zwykle przy Piotrusiu, gdy komórka zadzwoniła melodią Nokia Tune, a na wyświetlaczu pojawiło się: „Dziennikarz Strzygoń Dupek” (Kuźmińska \& Kuźmiński, 2015, s. 207).

W przykładzie nr 7 znajdujemy nazwę innej firmy i jej produktu - samsung.

W 1992 roku powstał pierwszy smartfon, wprowadzony na rynek w następnym roku. Był to kolejny przełom w komunikacji międzyludzkiej. Do funkcji

\footnotetext{
1 Aperol to gatunek włoskiego likieru.
} 
telefonu dołączono: kalendarz, książkę adresową, kalkulator, notatnik, pocztę elektroniczną, gry („Smartfon”, 2021). Można powiedzieć, że zatarła się granica między telefonem a komputerem, bo smartfonem da się wykonywać wiele czynności, które wcześniej były właściwe tylko komputerowi.

(20) [...] rozdzwonił się Józkowy smartfon, na którym pojawiło się zdjęcie kwadratowej twarzy i nazwisko „Wendelin Pysior” (Kuźmińska \& Kuźmiński, 2015, s. 88).

(21) - Czekaj, oni mają historię tej renowacji opisaną na stronie internetowej. - Wiolka uruchomiła smartfona (Kuźmińska \& Kuźmiński, 2019, s. 141).

(22) - Jak chcesz, to mogę ci znaleźć hotel. - Sięgnął po smartfona (Kuźmińska \& Kuźmiński, 2019, s. 280).

(23) - Tak, naprawdę was widzę - powiedział, a potem uniósł smartfona, z którego konwersował z zebranymi (Mróz, 2019, s. 276.)

W 2007 roku firma Apple wyprodukowała smartfon zwany iPhone. Łączy on funkcje telefonu, platformy rozrywkowej, komunikatora internetowego i przeglądarki (,iPhone”, 2021).

(24) Ze sparowanego z samochodem iPhone’a płynęły dźwięki podobne do tych, które niegdyś wypełniały niewielkie mieszkanie przy placu Lenina (Mróz, 2019, s. 389).

(25) Mężczyzna wyciąga iPhone’a, udaje, że przegląda wiadomości, wycisza dźwięk, ustawia aparat fotograficzny (Szczygieł, 2018, s. 319).

Pojawia się też zapis ajfon, we fragmencie przekazującym wypowiedź po angielsku - polską ortografią:

(26) - Foto! - powtarza student, nie uśmiecha się, ale nie ma w nim również agresji. Giw mi jur ajfon... (Szczygieł, 2018, s. 321).

W powieści występuje nazwa jednego z modeli smartfona - blackberry ${ }^{2}$.

(27) W prawej ręce pojawiła się komórka, w lewej pełna wody butelka. Edling od razu rozpoznał swój model blackberry (Mróz, 2019, s. 279).

Powyższy cytat (nr 27) dowodzi, że komórka jest hiperonimem smartfona; w cytacie nr 23 użyto słowa smartfon, a chodzi o ten sam przedmiot. Kolejny cytat nr 28 pokazuje z kolei, że hiperonimem komórki jest telefon:

(28) Zanim jednak miała ku temu okazję, rozległ się standardowy dzwonek blackberry.

Gerard przeprosił i sięgnął po telefon (Mróz, 2019, s. 197).

${ }^{2}$ W języku angielskim 'jeżyna’. 


\section{Komputery}

O ile słowa dotyczące telefonii, a poświadczone we współczesnej polskiej prozie są po raz pierwszy przedmiotem mojego zainteresowania, o tyle terminologia komputerowa była już przeze mnie poruszana $\mathrm{w}$ artykule Internet $w$ literaturze pięknej (Tyrpa, w druku). Dlatego pominę tu wyrazy omówione w tej pracy. Należą do nich nazwy różnych rodzajów urządzeń: komputer, laptop, tablet, notebook i firm je produkujących (Dell). Wiele słów wiąże się z Internetem: sieć, net, wi-fi, z pocztą elektroniczną: poczta, skrzynka, mail, e-mail, wiadomość, spam. Niektóre dotyczą części komputera i jego programów: twardy dysk, wyszukiwarka, Google, (wy)guglać, aplikacja. Inne wiążą się z różnymi formami korzystania indywidualnego lub zbiorowego z możliwości czerpania wiedzy i wymiany wiadomości: strona, website, wpis, blog, gg, Facebook, gra. Są też terminy techniczne: pendrive, skanować. Trzeba jeszcze dodać, że nie wszystkie wymienione leksemy są używane w literaturze pięknej w swoim podstawowym znaczeniu. Bywa tak, że pisarze traktują je jako składniki nowych środków stylistycznych (porównań, metafor).

$\mathrm{W}$ dalszym ciągu przedstawię kolejne wyrazy mieszczące się w polu semantycznym KOMPUTER. Na kartach powieści występują nazwy rodzajów komputerów. Palmtop to komputer wielkości dłoni (STM, 2006, s. 98):

(29) Czytelnia była pusta, nie licząc staruszka pochylonego nad jakimś opasłym tomiszczem z nowoczesnym palmtopem i lupą w oku (Bator, 2012, s. 399).

Do palmtopa podobny jest iPod - przenośny odtwarzacz multimedialny („iPod”, 2020):

(30) Pochyliliśmy się nad ekranem iPoda (Bator, 2012, s. 474).

W powieści spotykamy jeszcze określenie superkomputer, odnoszące się do rodzaju bardzo szybkiego, potężnego komputera:

(31) - I co, wrzucą te zdjęcia w superkomputer, który zrobi wirtualną rekonstrukcję albo, nie wiem, analizę DNA na podstawie fotografii? (Kuźmińska \& Kuźmiński, 2019, s. 58).

Natomiast słowo maszynka można uznać za hiperonim zastosowany z odcieniem żartobliwym:

(32) A potem jeszcze dodal, ze obslugi tej maszynki mozna nauczyc nawet szympansa, ale zeby cos z tego zrozumiec, potrzebna jest inteligencja (Dunin, 1998, s. 6). 
Dodajmy, że cytat nr 32 jest fragmentem e-maila z czasów, gdy jeszcze nie używano znaków diakrytycznych charakterystycznych dla polskich liter.

Na kartach powieści pojawiają się nazwy firm produkujących komputery i nazwy tych produktów. Firma Apple została założona w Kalifornii przez Steve'a Wozniaka w 1976 roku Nazwa firmy przechodzi na jej produkty, tu apple (podobnie jak dzieje się z telefonami komórkowymi, cytaty $\mathrm{nr} 7,18,19$ ). MacBook była to seria laptopów firmy Apple z lat 2006-2011 („Apple Inc.”, 2021; „MacBook”, 2020). Spolszczona forma nazwy tego typu brzmi Mak:

(33) Z chęcią pożyczę ci tamtego MacBooka. Nie jest nowy, kupiłam go na Allegro, ale ma przyzwoite parametry. [...] Do tak dużego projektu, jaki mu zlecono, potrzebował szybkiego, niezawodnego laptopa o dużej pamięci operacyjnej i sporej pojemności dysku. Maki takie właśnie były. Dziewczyna wybiegła z kuchni, by wrócić po chwili z przyciężkim, przestarzałym modelem apple’a [...] (Michalak, 2018, s. 82).

Wspomniana powyżej internetowa platforma handlowa Allegro została założona w 1999 roku w Poznaniu („Allegro”, 2021).

Bohaterowie współczesnych powieści są na bieżąco ze sprawami związanymi z komputerem, dlatego operują terminami informatycznymi, na przykład nazwami programów, serwisów, komunikatorów internetowych:

(34) - Muszę jeszcze zainstalować sterowniki karty sieciowej i ściągnąć aktualizacje Windowsa. - Jasiu, dlaczego nie przejdziecie na Linuxa? Ja go lubię osobiście i uważam, że jest bezpieczniejszy. - Daj spokój, teraz się szkolić w Linuxie. Windowsa wszyscy znają, niech zostanie, jak jest (Szwaja, 2011b, s. 32).

Windows to system operacyjny stworzony i rozwijany przez Microsoft Corporation, znany od 1985 roku (STM, 2006, s. 232). Linux jest systemem operacyjnym stworzonym przez Fina Linusa Torvaldsa w 1991 roku. Jego nazwa jest wynikiem kontaminacji imienia twórcy i nazwy systemu operacyjnego Unix („Linux”, 2021). Nazwa firmy Microsoft też pojawia się w tekstach literackich:

(35) Może Microsoft wypuścił specjalną czcionkę przeznaczoną do pisania tajemniczych listów (Bator, 2012, s. 293).

(36) - Alan Gates - odpowiedziałam zimno. G jak Genowefa. Gates. G-a-t-e-s. Imię jak jak z „Greka Zorby”, a nazwisko jak tego gościa od Microsoftu (Szwaja, 2011a, s. 49).

W tekstach powieści zarejestrowano nazwy dwóch programów graficznych - Corela (istniejącego od roku 1989) i Photoshopu (od roku 1990):

(37) - Ale ja nie mogę jechać bez komputera - pisnęła Marysia. - Mam tam wszystkie swoje wiersze! I grafikę! [...] Grafice damy wolne, kupię ci farby i karton. Albo kredki świecowe. - Nie masz, ciociu, Corela? (Szwaja, 2013, s. 84). 
(38) Odpowiedź znalazła na billboardzie po drugiej stronie drogi. Kobieta z powiększonym w Photoshopie uśmiechem patrzyła na nią z politowaniem, prezentując swoje idealne ciało bez wieku, bez zmarszczek i bez żadnej skazy (Kuźmińska \& Kuźmiński, 2019, s. 259).

Excel jest to arkusz kalkulacyjny dla systemów Windows („Microsoft Excel”, 2021). W reportażu Mariusza Szczygła pewna osoba wpisała do niego najważniejsze fakty ze swego życia, nazywając rubryki: sukcesy, porażki i stresy:

(39) Niech pan zobaczy: do dzisiaj 504 sukcesy, 17 porażek i 93 stresy. To jest Excel mojego życia (Szczygieł, 2018, s. 57).

Komunikowaniu się służą przede wszystkim komunikatory, dostępne w Internecie. Dzięki nim można w czasie rzeczywistym wymieniać teksty. Taka komunikacja to czat (z angielskiego chat 'pogawędka') (STM, 2006, s. 27) . $^{3}$

(40) Już miała zamknąć przeglądarkę, gdy z charakterystycznym dźwiękiem otworzyło się okienko czatu (Kuźmińska \& Kuźmiński, 2015, s. 38).

(41) Czat zalała fala wiadomości (Mróz, 2019, s. 204).

(42) Czat był zablokowany, dopiero po chwili okienko znów się pojawiło (Mróz, 2019, s. 277).

W 2000 roku powstał komunikator Gadu-Gadu. STM (STM, 2006, s. 100) podaje, że w 2006 roku był on jednym z dwóch najpopularniejszych komunikatorów internetowych w Polsce. Aplikację dla rynku polskiego stworzył Łukasz Foltyn („GG”, 2021).

(43) Spotykał na offshorach młodych Polaków, przeważnie po studiach na Akademiach Morskich w Gdyni i Szczecinie, dobrze wykształconych i przygotowanych do pracy na morzu [...] część miała na lądzie żony, czasem dzieci - ci z reguły byli zadowoleni z życiowego wyboru, wolne chwile spędzali przy Skajpie albo na Gadu-Gadu i nosili zdjęcia wybranek w portfelach (Szwaja, 2009, s. 325).

Innym komunikatorem jest Messenger, powstały w roku 2008, powiązany z Facebookiem („Facebook Messenger”, 2021).

(44) Od czasu, kiedy w 2009 roku [...] zacząłem zbierać materiał do tej książki, zmarło wiele bliskich mi osób. [...] Lubią przyjść mailem lub Messengerem (Szczygieł, 2018, ss. 7-8).

Wspomniany powyżej (przykład nr 43) Skype znany w Polsce od 2005 roku pozwala na rozmowy połączone z widzeniem się interlokutorów („Skype”, 2021; STM, 2006, s. 196;). Obok pisowni spolszczonej pojawia się też oryginalna:

3 Czat stał się przedmiotem rozważań kilku artykułów Leszka Szymańskiego (Szymański, 2009, 2011, 2012, 2013) i Ewy Jędrzejko (Jędrzejko, 2012). 
(45) - Nie martw się, tato. Będziemy do ciebie przyjeżdżać jak najczęściej. [...] Komórki mamy. Skype’a. Ja cię teraz tak łatwo nie puszczę, straciłam ojca jako szczeniak, teraz życzę sobie go mieć. Stale i wciąż (Szwaja, 2008, s. 137).

Innym sposobem wymiany myśli jest serwis społecznościowy Twitter, udostępniający usługę mikroblogowania od 2006 roku („Twitter”, 2021):

(46) Trolle zwykły się wyżywać na Facebooku i Twitterze, bo wyłączył w serwisie możliwość komentowania artykułów - gdy to ogłosił, reszta medialnej branży pukała się w głowę, a po cichu szczerze mu zazdrościła (Kuźmińska \& Kuźmiński, 2019, s. 181).

Trollem nazywa się osobę ośmieszającą i obrażającą wpisami w Internecie innych użytkowników forów i czatów. Nazwa ta nawiązuje do stwora z mitologii nordyckich, choć u źródła stoi angielskie wyrażenie trolling for fish 'zarzucanie haczyka na rybę', co przenośnie oznacza poruszanie kontrowersyjnego tematu („Trollowanie”, 2021).

Post opublikowany na Twitterze zowie się tweet (ang. 'świergotać, ćwierkać). W cytacie nr 47 słowo zostało użyte jako człon porównania. Tweet oznacza tu coś ulotnego, szybko znikającego.

(47) Przyglądał się bąbelkom, które odrywały się od dna kieliszka, wirowały w złocistym płynie, żeby rozprysnąć się na powierzchni miniaturowym fajerwerkiem. Jeden za drugim, na wyścigi, pod ciśnieniem, choć puste w środku, wzburzając, wzbudzając pianę. I znikając. Jak newsy, headline’y, komentarze i tweety (Kuźmińska \& Kuźmiński, 2019, s. 418).

Istnieje też termin retweet 'przekazanie tweetu innym osobom':

(48) - Wszyscy cię cytują, od ambasady Izraela po Cejrowskiego. Zobacz sobie, ile masz udostępnień, retweetów, kto cię podał dalej i z jakim komentarzem (Kuźmińska \& Kuźmiński, 2019, s. 85).

Niektóre serwisy specjalizują się w kolekcjonowaniu i udostępnianiu materiałów wizualnych. Do nich należy powstały w 2020 roku w Stanach Zjednoczonych Pinterest („Pinterest”, 2021):

(49) Wrzucał urocze, pełne życia szkice na Pinterest, żeby nie zginęły w razie awarii komputera [...] (Michalak, 2018, s. 65).

$\mathrm{Na}$ istniejącym od 2005 roku YouTube można bezpłatnie umieszczać, oglądać, oceniać i komentować filmy („YouTube”, 2021).

(50) Uruchomiła film na YouTubie (Kuźmińska \& Kuźmiński, 2019, s. 34). 
Z kolei Twitch to platforma medialna udostępniająca wideo strumieniowe (na żywo) - głównie gier komputerowych i rozgrywek sportu elektronicznego, utworzona w 2011 roku („Twitch”, 2021).

(51) - To jak Twitch. Taki serwis, gdzie ludzie streamują... no, w sumie sporo rzeczy, ale przede wszystkim game-playe, jakieś swoje mądrości, grają covery znanych kawałków, wchodzą w interakcje z widzami... (Mróz, 2019, s. 202).

Występujący w powyższym cytacie czasownik streamować pochodzi od angielskiego stream 'strumien'.

W 2001 roku zaczęła powstawać Wikipedia, wielojęzyczna encyklopedia internetowa, działająca zgodnie z zasadą otwartej treści. Jej slogan głosi: „Wolna encyklopedia, którą każdy może redagować”. I o niej jest mowa w powieściach:

(52) Ale za to pierwszy raz napisał prawdę. Nie prawdę, którą się znajduje w Wikipedii, wyciąga od zaskoczonego przechodnia czy wynosi z konferencji prasowej, ale taką prawdziwą prawdę, za którą się zapłaciło karierą (Kuźmińska \& Kuźmiński, 2015, ss. 330-331).

(53) Dla leniuszków zrzynających z Wikipedii i ekologów recyklingujących prace kolegów z poprzedniego semestru Anka nie miała litości (Kuźmińska \& Kuźmiński, 2019, s. 34).

(54) Oficjalne strony i Wikipedię tylko przescrollował, nie szukał politycznie poprawnej laurki ani obrazka do folderu o spotkaniu kultur (Kuźmińska \& Kuźmiński, 2019, s. 68).

Czasownik przescrollować pochodzi od angielskiego to scroll 'przewijać'. STM (STM, 2006, s. 193) podaje dwa hasła: Scroll i Scrolling, tłumacząc, że chodzi o pasek przesuwający się u dołu ekranu telewizora lub o program umożliwiający przesuwanie zawartości okna w monitorze komputera. Utrwalono w powieści też postać niedokonaną czasownika:

(55) Sennie scrollowała przez tablicę, oglądając zdjęcia cudzych dzieci, cudzych obiadów, cudzych wakacji, okraszone garstką mało zabawnych memów i wyciskających łzy akcji społecznych na rzecz głodnych lub chorych dzieci i dręczonych kobiet gdzieś bardzo daleko (Kuźmińska \& Kuźmiński, 2015, s. 38).

Mem (z greckiego memesis 'naśladownictwo') to komunikat obrazkowy („Mem internetowy”, 2021).

Używany jest też polski ekwiwalent angielskiego czasownika to scroll przewijać:

(56) Przewijała ekran (Kuźmińska \& Kuźmiński, 2019, s. 141).

W Internecie można przeprowadzać operacje handlowe. Do tego służą sklepy on-line: 
(57) Jemu, Natanielowi Domaradzkiemu, proponowano opracowanie nowego logo dla firmy i wykonanie strony internetowej ze sklepem online (Michalak, 2018, ss. 62-63).

Ogólne określenie aplikacji internetowych umożliwiających wymianę wiadomości i interaktywny dialog to media społecznościowe. Jak pisze Iwona Loewe: „Internet jako środek masowej komunikacji spełnia naturalnie trzy podstawowe funkcje przypisywane każdemu innemu medium, czyli informacyjną, fatyczną i eskapistyczną" (Loewe, 2006, s. 93). Media społecznościowe pełnią wszystkie te funkcje, lecz chyba głównie - fatyczną. A oto użycia tego wyrażenia w powieściach:

(58) - Ale media społecznościowe to kopalnia, z której wygrzebiesz wszystko (Mróz, 2019, s. 390).

(59) W mediach społecznościowych starał się nie wdawać w dyskusje z hejterami albo w ogóle nie czytać ich komentarzy (Kuźmińska \& Kuźmiński, 2019, s. 181).

(60) Wyglądała na kobietę, która napisała doktorat o niezrozumiałym tytule i gardzi mediami społecznościowymi, ale umie upiec sernik i od lat uprawia jakiś wymagający sport (Bator, 2017, s. 16).

Jedną z form dzielenia się przemyśleniami na jakiś temat lub informacjami są blogi (z ang. weblog), rodzaj dzienników (pamiętników) prowadzonych w Internecie (STM, 2006, ss. 18-19) ${ }^{4}$.

(61) Odkąd Raport Strzygonia z bloga rozwinął się w trendujący serwis dziennikarskiego kolektywu, Bastian nie miał czasu pisać (Kuźmińska \& Kuźmiński, 2019, s. 24).

Autor bloga to bloger 5

(62) - Świetnie, że wreszcie zaczynasz zdradzać objawy posiadania uczuć, ale opublikowałeś to jako Bastian „Jestem Dziennikarzem” Strzygoń na portalu www.raportstrzygonia.pl, a nie jako bloger na stronce www.subiektywneemocjebastiana.pl albo anonimowy internauta w serwisie www.wspomnieniazdziecinstwa.pl - syczała do telefonu (Kuźmińska \& Kuźmiński, 2019, s. 84).

Zbiór blogów nazywany jest blogosferą ${ }^{6}$.

${ }^{4}$ Blogi były tematem artykułów Joanny Aleksandruk (Aleksandruk, 2012), Julii Legomskiej (Legomska, 2015) i Joanny Ginter (Ginter, 2018).

${ }^{5}$ Wyraz ten może być przykładem na szybkie zmiany w terminologii internetowej. Osiem lat temu używano słowa blogowicz (Aleksandruk, 2012, ss. 89, 90).

${ }^{6}$ Blogosferą tematyczną zajęła się Dorota Suska (Suska, 2015). Wymienia ten termin też J. Aleksandruk (Aleksandruk, 2012, s. 90), objaśniając go jako 'sieć społeczna piszących'. 
(63) Mam nadzieję, że jak zwykle w upalny wieczór siedzisz przy swoim biurku, jednym okiem błądząc po blogosferze i poczcie na przemian, a drugim czytając Ellery’ego (Musierowicz, 2014, s. 33).

Bardzo często internauci używają pseudonimów, zwanych nickami (z angielskiego nickname 'przezwisko'; STM, 2006, s. 129)'.

(64) Edling zobaczył, że wystarczy wpisać nick, by wziąć udział w tym, co się działo (Mróz, 2019, s. 202).

(65) Dopiero kiedy przewinął kawałek wyżej, zobaczył, że do rozmowy włączył się administrator - jego nick, „Iluzjonista”, był wyróżniony na czerwono i pogrubiony (Mróz, 2019, s. 275).

Aktywność w sieci wyraża się komentowaniem tekstów napisanych przez innych. Komentarz jako gatunek wypowiedzi został scharakteryzowany w STM (STM, 2006, ss. 96-97). Przykłady powieściowych użyć w Internecie w cytatach nr 47, 48, 68. Akceptację internauci wyrażają przez naciśnięcie klawisza like (w angielskiej wersji), co zostało w polszczyźnie przyjęte jako lajk (Niepytalska-Osiecka, 2014; Zemlanaja, 2016).

(66) Wiolka czekała na betonowym placu, sprawdzając statystyki transmisji na żywo. W szczytowym momencie były sto siedemdziesiąt trzy osoby. Nieźle. Średni czas uczestnictwa czterdzieści trzy sekundy. Szesnaście lajków (Kuźmińska \& Kuźmiński, 2019, s. 231).

W polskiej wersji przycisk oznaczony jest lubię to:

(67) Wystarczy kliknąć „Lubię to!” i już można z czystym sumieniem wrócić do problemów pierwszego świata (Kuźmińska \& Kuźmiński, 2015, s. 38).

Kliknąć to 'nacisnąć klawisz myszy komputerowej'. Polubić to 'nacisnąć klawisz lubię to':

(68) Zalogowała się na Facebooku. Parę osób polubiło jej wpis, pojawił się jeden komentarz [...] (Kuźmińska \& Kuźmiński, 2015, s. 38).

Zalogować się znaczy 'podać swój identyfikator i hasło w celu uzyskania dostępu do komputera lub sieci komputerowej'. Pochodzi od angielskiego to log in („Logowanie”, 2020).

Anna Niepytalska-Osiecka (Niepytalska-Osiecka, 2014) omówiła internetowe zapożyczenie z języka angielskiego - hejt, jego zaadaptowane postaci -

7 O tym rodzaju antroponimów pisali Alina Naruszewicz-Duchlińska (Naruszewicz-Duchlińska, 2015) i Marcin Kojder (Kojder, 2015). 
hejtować i hejcić oraz derywaty hejterski, hejtowy, shejtować, zhejtować, shejcić, zhejcić. Tak się składa, że żadna $\mathrm{z}$ tych form nie została poświadczona w moim materiale. Pojawiły się natomiast dwa inne derywaty - hejter ( $\mathrm{z}$ angielskiego hater) 'ten, kto zamieszcza w Internecie nienawistną wypowiedz's (cytaty 59 i 70) oraz pohejtować 'zamieszczać w Internecie nienawistne wypowiedzi':

(69) Napiszę, ktoś się wzburzy, ktoś pohejtuje, ktoś wzruszy ramionami, a potem wszyscy zapomną (Kuźmińska \& Kuźmiński, 2019, s. 418).

Trzecim wyrazem rozpatrywanym przez A. Niepytalską-Osiecką (Niepytalska-Osiecka, 2014, s. 344) jest fejk, który definiuje ona tak: 'sfałszowany profil internetowy lub inny obiekt elektroniczny pojawiający się w portalach społecznościowych'. W cytatach z polskiej prozy oznacza on raczej fałszywą wiadomość. Obok formy fejk stosowana jest fake (cytat nr 72). Występuje też wyrażenie fake news, przy czym news jest odmieniane jak polski rzeczownik rodzaju męskiego. Hasło News STM (STM, 2006, s. 129) odsyła do hasła Wzmianka (STM, 2006, s. 237), uznając wzmiankę za polski odpowiednik angielskich słów news i flash.

(70) Pewien hejter z Macedonii mówił wczoraj w telewizyjnym dokumencie na temat fake newsów, że prawdą są tylko nasze przeżycia. Wszystko inne jest wyłącznie manipulacją, a w rezultacie fejkiem (Szczygieł, 2018, s. 255).

(71) Za dostęp do opinii biegłego na temat kości Amalii Szachen zapłacił puszczeniem w świat niewinnego fake newsa. Wyssanej z palca historii o laserowym skanowaniu Dąbrowy [...] (Kuźmińska \& Kuźmiński, 2019, s. 418).

W powieści kryminalnej pojawił się termin deepfake, wyjaśniony przez jednego $\mathrm{z}$ bohaterów - informatyka:

(72) - Deepfake - powiedział. [...] Technologia, dzięki której możesz sprawić, że dowolna osoba powie to, co chcesz [...] Dopiero potem okazało się, że to sztuczna inteligencja. [...] Uczący się algorytm, który sprawia, że potem da się osiągnąć efekt takiego ruchu ust i mimiki, jakby słowa wypowiadała prawdziwa osoba [...] Niekiedy nie poznasz nawet, że to fake [...] (Mróz, 2019, ss. 135-137).

Na tym przerwę cytowanie terminów komputerowych z tekstów współczesnej polskiej prozy. Jest ich o wiele więcej i wciąż pojawiają się nowe. Komputery zaczęły odgrywać tak wielką rolę w XX i XXI wieku, czyli całkiem niedawno. Terminologia z nimi związana zmienia się na naszych oczach. Zauważmy też, że większość terminów dotyczących komputerów i telefonów to zapożyczenia

8 To zapożyczenie rozpatruje Natalia Zemlanaja (Zemlanaja, 2016, ss. 363-364). 
z języka angielskiego (często z jego amerykańskiej wersji). W powieściach pojawiają się one w postaci oryginalnej lub spolszczonej.

Wraz z niezwykle szybkim rozwojem technologii pewne urządzenia znikają, a wraz z nimi ich nazwy. Zacytuję fragment jedynej w moim zbiorze powieści wydanej jeszcze w XX wieku, która podjęła tematykę komputerową. Przedstawia on rozmyślania nastolatki:

(73) Komputerowcy to było kolejne odkryte, choć chyba najgorzej zbadane przez nią plemię. Komputerowcy mówili niezrozumiałym językiem i aby zostać pełnoprawnym członkiem ich plemienia, trzeba było tego języka się nauczyć. Zawsze byli bardzo zajęci i bez przerwy prowadzili między sobą wymiany - dyskietek na inne dyskietki, jakichś metalowych tajemniczych części na szare kabelki (Dunin, 1998, s. 15).

Ważne jest tu spostrzeżenie, że nowa, prężna dziedzina działalności ludzkiej powoduje powstanie nowej warstwy leksykalnej. Praca z komputerem dowodzi, że wciąż trzeba przyswajać nowe czynności, udogodnienia, rozwiązania i ich nazwy. Drugi wniosek, który można wyciągnąć z powyższego cytatu, to to, że wraz z szybkim rozwojem techniki niektóre nazwy znikają z obiegu wraz ze swoimi desygnatami. Tak stało się z dyskietką, która przestała być używana, a razem $\mathrm{z}$ tym - jej nazwa. Pisarze rejestrują na bieżąco istniejący stan rzeczy, a życie ciągle przynosi zmiany. Za jakiś czas powieści z pierwszego dwudziestolecia XXI wieku staną się dokumentem między innymi sposobu komunikowania się ludzi w tym czasie. Telefony i komputery przedstawione w tych tekstach wydadzą się przestarzałe. Jednak wartością powieści obyczajowych, kryminalnych oraz felietonów, malujących słowem teraźniejszość, jest to, że po czasie ocalą od zapomnienia między innymi ten aspekt życia społecznego Polaków na początku trzeciego tysiąclecia, jakim jest komunikacja międzyludzka.

\section{BIBLIOGRAFIA}

Aleksandruk, J. (2012). Blog jako gatunek mowy. W J. Szadura (Red.), Tekst-gatunek-dyskurs na przełomie XX $i$ XXI wieku (ss. 79-92). Polihymnia.

Allegro (strona internetowa). (2021). W Wikipedia, wolna encyklopedia. https://pl.wikipedia.org /w/index.php?title=Allegro_(strona_internetowa)\&oldid $=62975760$

Apple Inc. (2021). W Wikipedia, wolna encyklopedia. https://pl.wikipedia.org/w/index .php?title=Apple_Inc.\&oldid $=62861402$ 
Facebook Messenger. (2021). W Wikipedia, wolna encyklopedia. https://pl.wikipedia.org/wiki /Facebook_Messenger

GG (komunikator internetowy). (2021). W Wikipedia, wolna encyklopedia. https://pl.wikipedia.org /w/index.php?title=GG_(komunikator_internetowy)\&oldid=62509860

Ginter, J. (2018). O komunikowaniu się na blogach poświęconych poprawności językowej uwagi wstępne. Język Polski, 98(4), 47-58. https://doi.org/10.31286/JP.98.4.5

Greń, Z. (2015). Wariantywność formalna w procesie adaptacji anglicyzmów w języku słowackim. W D. Roszko \& J. Satoła-Staśkowiak (Red.), Semantyka a konfrontacja językowa 5 (ss. 125-137). Instytut Slawistyki Polskiej Akademii Nauk (Slawistyczny Ośrodek Wydawniczy).

Greń, Z., Holly, K., Itoya, B., Mętrak, M., Smółkowa, T., \& Żółtak, A. (Red.). (2016). Języki zachodniosłowiańskie wobec pożyczek angielskich w ostatnim dwudziestoleciu: Gramatyka, leksyka, pragmatyka, uwarunkowania społeczno-kulturowe. Instytut Języka Polskiego Polskiej Akademii Nauk.

Holly, K., \& Żółtak, A. (2016). Sfery, pola i subpola tematyczne. W Z. Greń, K. Holly, B. Itoya, M. Mętrak, T. Smółkowa, \& A. Żółtak (Red.), Języki zachodniosłowiańskie wobec pożyczek angielskich w ostatnim dwudziestoleciu: Gramatyka, leksyka, pragmatyka, uwarunkowania społeczno-kulturowe (ss. 202-211). Instytut Języka Polskiego Polskiej Akademii Nauk.

iPhone. (2021). W Wikipedia, wolna encyklopedia. https://pl.wikipedia.org/w/index.php? title $=$ IPhone\&oldid $=62071602$

iPod. (2020). W Wikipedia, wolna encyklopedia. https://pl.wikipedia.org/w/index.php?title $=$ IPod\&oldid $=60996959$

Jędrzejko, E. (2012). Język w sieci - czyli jeszcze o czacie i innych formach komunikacji internetowej: Nowe media - nowy styl? Socjolingwistyka, 26, 7-22.

Kojder, M. (2015). Identyfikatory internetowe użytkowników tematycznego forum internetowego RowerowyLublin. W I. Sarnowska-Giefing, M. Balowski, \& M. Graf (Red.), Funkcje nazw własnych w kulturze i komunikacji (ss. 259-268). Instytut Naukowo-Wydawniczy „Maiuscula”.

Legomska, J. (2015). Quazi-onimy jako wyraz internetowej interaktywności (O funkcji interaktywnej w literaturze Sieci). W I. Sarnowska-Giefing, M. Balowski, \& M. Graf (Red.), Funkcje nazw własnych w kulturze i komunikacji (ss. 331-340). Instytut Naukowo-Wydawniczy „Maiuscula”.

Linux. (2021). W Wikipedia, wolna encyklopedia. https://pl.wikipedia.org/w/index.php?title $=$ Linux\&oldid $=62896329$

Loewe, I. (2006). Internet i jego zasoby w polskich badaniach lingwistycznych: Rekonesans. Biuletyn Polskiego Towarzystwa Językoznawczego, 62, 93-103.

Logowanie. (2020). W Wikipedia, wolna encyklopedia. https://pl.wikipedia.org/w/index.php?title $=$ Logowanie\&oldid $=60252075$

MacBook. (2020). W Wikipedia, wolna encyklopedia. https://pl.wikipedia.org/w/index.php?title $=$ MacBook\&oldid $=61262606$

Mem internetowy. (2021). W Wikipedia, wolna encyklopedia. https://pl.wikipedia.org/w/index.php ?title=Mem_internetowy\&oldid $=62996329$

Microsoft Excel. (2021). W Wikipedia, wolna encyklopedia. https://pl.wikipedia.org/w/index.php ?title=Microsoft_Excel\&oldid=62849524 
Naruszewicz-Duchlińska, A. (2015). Pseudonimy internetowe (nicknames) jako forma autocharakterystyki. W I. Sarnowska-Giefing, M. Balowski, \& M. Graf (Red.), Funkcje nazw własnych w kulturze i komunikacji (ss. 439-448). Instytut Naukowo-Wydawniczy „Maiuscula”.

Nieckula, F. (1993). Język ustny a język pisany. W J. Bartmiński (Red.), Encyklopedia kultury polskiej XX wieku: T. 2. Współczesny język polski (ss. 101-114). Wiedza o Kulturze.

Niepytalska-Osiecka, A. (2014). O fejku, lajku i hejcie w polszczyźnie internetowej. Język Polski, 94(4), 343-352.

Pinterest. (2021). W Wikipedia, wolna encyklopedia. https://pl.wikipedia.org/w/index.php?title $=$ Pinterest\&oldid $=62143041$

Pisarek, W. (Red.). (2006). Słownik terminologii medialnej [STM]. Towarzystwo Autorów i Wydawców Prac Naukowych „Universitas”.

Skype. (2021). W Wikipedia, wolna encyklopedia. https://pl.wikipedia.org/w/index.php?title $=$ Skype\&oldid $=62106519$

Smartfon. (2021). W Wikipedia, wolna encyklopedia. https://pl.wikipedia.org/w/index.php?title $=$ Smartfon\&oldid $=62908792$

Smółkowa, T. (2015). Języki zachodniosłowiańskie wobec pożyczek angielskich w ostatnim dwudziestoleciu - gramatyka, leksyka, pragmatyka, uwarunkowania społeczno-kulturowe. Studia z Filologii Polskiej i Słowiańskiej, 50, 223-236. https://doi.org/10.11649/sfps.2015.013

Suska, D. (2015). Strategie nazewnicze w blogosferze tematycznej (na przykładzie nazw blogów kulinarnych). W I. Sarnowska-Giefing, M. Balowski, \& M. Graf (Red.), Funkcje nazw własnych w kulturze i komunikacji (ss. 619-629). Instytut Naukowo-Wydawniczy „Maiuscula”.

Szymański, L. (2009). Analiza wypowiedzi z czatu internetowego. Biuletyn Polskiego Towarzystwa Językoznawczego, 65, 165-174.

Szymański, L. (2011). Empiryczna analiza leksyki czatu internetowego. Język Polski, 91, 179-187.

Szymański, L. (2012). Konwencje zapisu wyrazów na czacie internetowym. Język Polski, 92, 20-36.

Szymański, L. (2013). Wybrane aspekty badań kwantytatywnych pogawędek sieciowych. Rozprawy Komisji Językowej ŁTN, 59, 263-272.

Trollowanie. (2021). W Wikipedia, wolna encyklopedia. https://pl.wikipedia.org/w/index.php ?title $=$ Trollowanie\&oldid $=62610936$

Twitch. (2021). W Wikipedia, wolna encyklopedia. https://pl.wikipedia.org/w/index.php?title $=$ Twitch\&oldid $=62988347$

Twitter. (2021). W Wikipedia, wolna encyklopedia. https://pl.wikipedia.org/w/index.php?title $=$ Twitter\&oldid $=62976764$

Tyrpa, A. (w druku). Internet w literaturze pięknej. W D. Stolac \& A. Vlastelić (Red.), Generacija Interneta / The Internet generation. Hrvatska sveučilišna naklada; Sveučilište u Rijeci, Filozofski fakultet.

YouTube. (2021). W Wikipedia, wolna encyklopedia. https://pl.wikipedia.org/w/index.php?title =YouTube\&oldid=62991335

Zemlanaja, N. (2016). Fighter, hejter i headliner, czyli o wyrażeniach pochodzenia angielskiego we współczesnej polszczyźnie (na materiale czasopisma Polityka). W H. Kurek, M. Święcicka, \& M. Peplińska (Red.), Globalizacja a przemiany języków słowiańskich (ss. 354-368). Wydawnictwo Uniwersytetu Kazimierza Wielkiego. 


\section{ŹRÓDŁA}

Bator, J. (2012). Ciemno, prawie noc. Wydawnictwo W.A.B.

Bator, J. (2017). Purezento. Społeczny Instytut Wydawniczy Znak.

Dunin, K. (1998). Tabu. Wydawnictwo W.A.B.

Kuźmińska, M., \& Kuźmiński, M. (2015). Śleboda. Wydawnictwo Dolnośląskie.

Kuźmińska, M., \& Kuźmiński, M. (2019). Mara. Wydawnictwo Dolnośląskie.

Michalak, K. (2018). Kropla nadziei. Społeczny Instytut Wydawniczy Znak.

Mróz, R. (2019). Iluzjonista. Wydawnictwo FILIA.

Musierowicz, M. (2014). Wnuczka do orzechów. AKAPIT PRESS.

Szczygieł, M. (2018). Nie ma. Wydawnictwo Dowody na Istnienie.

Szwaja, M. (2005). Artystka wędrowna. Prószyński i S-ka.

Szwaja, M. (2008). Dziewice, do boju! Wydawnictwo SOL.

Szwaja, M. (2009). Gosposia prawie do wszystkiego. Wydawnictwo SOL.

Szwaja, M. (2011a). Jestem nudziarą. Prószyński Media.

Szwaja, M. (2011b). Nie dla mięczaków: Historia krótkiej wolności Piotra V. Empik.

Szwaja, M. (2013). Romans na receptę. Prószyński Media.

\section{Słownictwo z zakresu komunikacji międzyludzkiej w polskich tekstach literackich}

Powieści obyczajowe i kryminalne o akcji rozgrywającej się w XXI wieku rejestrują wszelkie zjawiska społeczne. Do nich można zaliczyć sposoby komunikowania się ludzi, tak różne od tych sprzed 40 lat. Utwory literackie dostarczają nazw urządzeń (komputer, laptop, palmtop, iPhone, iPad, tablet, smartfon) oraz firm je produkujących (Dell, Apple, Nokia, Samsung). Znajdujemy w nich nazwy programów komputerowych (Windows, Word, Excel), mediów społecznościowych (Facebook), komunikatorów (Messenger). Nie brak określeń czynności wykonywanych w trakcie ich używania (zalogować się, kliknąć, mailować, guglać). Absolutna większość tych słów pochodzi z języka angielskiego i ma zasięg międzynarodowy.

Słowa kluczowe: słownictwo telefoniczne, słownictwo komputerowe, anglicyzmy, powieści polskie 


\section{Vocabulary Concerning Human Communication in Polish Literary Texts}

Novels that cover action taking place in the 21st century refer to all kinds of social phenomena, including the ways in which people communicate, which are very different from those popular only 40 years ago. Literary works provide the names of devices (computer, laptop, palmtop, iPhone, iPad, tablet, smartphone), as well as the companies which manufacture them (Dell, Apple, Nokia, Samsung). Novels include the names of computer software (Windows, Word, Excel), social media (Facebook), and internet communicators (Messenger). There are also words that denote the activities performed while using these devices and applications (to $\log$ in, to click, to email, to google). The majority of these words originate from English and have international scope.

Keywords: telephone vocabulary, computer vocabulary, anglicisms, Polish novels

\section{Notka o autorce}

Anna Tyrpa (anna.tyrpa@ijp.pan.pl) - prof.dr hab., pracuje w Instytucie Języka Polskiego Polskiej Akademii Nauk, opublikowała między innymi: Frazeologia somatyczna. Zwiazzki frazeologiczne o znaczeniach motywowanych cechami części ciała w gwarach polskich (Łask, 2005), Cudzoziemcy i obce kraje $w$ dialektach polskich (Kraków, 2011), jest współautorką następujących słowników: Słownik wymowy polskiej (Warszawa-Kraków, 1977), Słownik gwar polskich (1979-2015), Słownik stereotypów i symboli ludowych (Lublin, 2012), Słownik gwar małopolskich (Kraków, 2016, 2017), Słownik gwar Ostródzkiego, Warmii i Mazur (Warszawa-Kraków, 2018, 2021). Zainteresowania naukowe: dialektologia, etnolingwistyka, frazeologia, język współczesnych powieści polskich.

Anna Tyrpa (anna.tyrpa@ijp.pan.pl) - professor, PhD, works at the Institute of Polish Language of the Polish Academy of Sciences. Author of the following books: Frazeologia somatyczna. Związki frazeologiczne o znaczeniach motywowanych cechami części ciała w gwarach polskich (Łask, 2005), Cudzoziemcy i obce kraje $w$ dialektach polskich (Cracow, 2011). Co-author of the following 
lexicons: Słownik wymowy polskiej (Warsaw-Cracow, 1977), Słownik gwar polskich (1979-2015), Słownik stereotypów i symboli ludowych (Lublin, 2012), Słownik gwar małopolskich (Cracow, 2016, 2017), Słownik gwar Ostródzkiego, Warmii i Mazur (Warsaw-Cracow, 2018, 2021). Scientific interests: dialectology, ethnolinguistics, phraseology, language of contemporary Polish novels.

Publication History: Received: 2020-10-09; Accepted: 2021-04-11; Published: 2021-12-23 